\title{
Cellular fatty acyl and alkenyl residues in Megasphaera and Pectinatus species: contrasting profiles and detection of beer spoilage
}

\author{
Ilkka M. Helander' and Auli Haikara ${ }^{2}$
}

1 Department of Bacterial Vaccine Research and Molecular Biology, National Public Health Institute, Mannerheimintie 166, FIN-00300 Helsinki, Finland

2 VTT Biotechnology and Food Research, FIN-02150 Espoo, Finland
Author for correspondence: Ilkka M. Helander. Tel: +358 0 4744562. Fax: +358 04744697. e-mail: Ilkka.Helander @ktl.fi

\begin{abstract}
The strictly anaerobic Gram-negative beer spoilage bacteria Megasphaera cerevisiae, Pectinatus cerevisiiphilus and P. frisingensis were subjected to cellular fatty acid analysis, employing acid- and base-catalysed cleavage, gas chromatography and mass spectrometry. $M$. cerevisiae contained 12:0, 16:0, $16: 1,18: 1,17:$ cyc, 19:cyc, 12:0(3OH), 14:0(3OH) as the main fatty acids, and alk-1-enyl chains instead of acyl chains were detected to a considerable extent (14\% of total fatty acids), indicating the presence of plasmalogens. The fatty acid pattern of $M$. cerevisiae was almost identical to that of $M$. elsdenii, the only species previously assigned to this genus. $P$. cerevisiiphilus and $P$. frisingensis yielded fatty acids that were heavily dominated by odd-numbered chains; 11:0, 15:0, 17:1, 18:cyc and 13:0(3OH) were the main fatty acids detected in both species. Alk-1-enyl chains with similar chain lengths were also found. Both Pectinatus species contained six different 3-hydroxy fatty acids with chain lengths between 11 and 15 carbons, 13:0(3OH) being dominant and the others accounting for generally less than $1 \%$ of total fatty acids. Among the minor components, an unsaturated 3-hydroxy fatty acid was detected which was shown to be $13: 1(30 H)$. In addition, fatty acid analysis was shown to be applicable to detection of bacterial contamination of beer.
\end{abstract}

Keywords: Megasphaera cerevisiae, Pectinatus cerevisiiphilus, Pectinatus frisingensis, fatty
acids

\section{INTRODUCTION}

Since the 1970s, strictly anaerobic Gram-negative bacteria assigned to the genera Pectinatus and Megasphaera have been recognized as spoilage organisms in packaged unpasteurized beer (Haikara, 1991). Their emergence has been associated with the advances in filling techniques resulting in decreased volumes of air in the head space of beer bottles and cans. The genus Pectinatus currently contains two species, P. cerevisiiphilus (Lee et al., 1978) and $P$. frisingensis (Schleifer et al., 1990), whereas the beer isolates of the genus Megasphaera have been named $M$. cerevisiae (Engelmann \& Weiss, 1985) to distinguish them from the only species previously assigned to this genus, the rumen bacterium $M$. elsdenii.

Abbreviations: $B S T F A, N, O-b i s(t r i m e t h y l s i l y l)$ trifluoroacetamide; $\mathrm{CD}_{3} \mathrm{OD}$, tetradeuteriomethanol; DMA, 1,1-dimethylacetals; FAMEs, fatty acid methyl esters; FID, flame ionization detector; LPS, lipopolysaccharide; TMS, 3-O-trimethyisilyl.
Cellular fatty acid analysis is a useful tool for investigating taxonomic relatedness of bacteria. Furthermore, fatty acid analysis could possibly serve in identifying spoilage organisms in beer. In this study we have analysed cellular fatty acids of $M$. cerevisiae, about which there is no previous information. Both species of the genus Pectinatus were also analysed, since there are contradictory data concerning the fatty acid composition; a recent report of the cellular fatty acids of Pectinatus (Moore et al., 1994) does not mention, for instance, the major 3-hydroxy fatty acid that we have described as a component of the lipopolysaccharide (LPS) of $P$. cerevisiiphilus and $P$. frisingensis (Helander et al., 1992, 1994).

\section{METHODS}

Bacterial strains and growth conditions. $M$. cerevisiae DSM 20462 (Engelmann \& Weiss, 1985) and VTT E-84195 (Haikara, 1991) and M. elsdenii ATCC 25940 were cultivated for $2 \mathrm{~d}$ at $30^{\circ} \mathrm{C}$ in PYF broth $(10 \mathrm{~g}$ peptone, $10 \mathrm{~g}$ yeast extract, and $20 \mathrm{~g}$ 
fructose, per litre) anaerobically, with stirring (250 r.p.m.) under nitrogen atmosphere. $P$. cerevisiiphilus ATCC $29359^{\mathrm{T}}$ and $P$. frisingensis ATCC $33332^{\mathbf{T}}$ were cultivated as above, but the medium was PYG broth (as PYF but fructose replaced by $20 \mathrm{~g}$ glucose $1^{-1}$ ). The bacteria were collected by centrifugation and freeze-dried.

Liberation and derivatization of fatty acids and fatty alk-1enyl chains. For each assay, 5-10 mg freeze-dried cells were used. Methanolysis ( $2 \mathrm{M} \mathrm{HCl}$ in methanol, $1 \mathrm{ml}$ ) was carried out in sealed tubes for $48 \mathrm{~h}$ at $100^{\circ} \mathrm{C}$. The lysate was filtered through glass wool, concentrated under $\mathrm{N}_{2}$ flow, and dissolved in n-hexane for gas chromatographic analysis. Tetradeuteriomethanol $\left(\mathrm{CD}_{3} \mathrm{OD}\right.$, Merck) was alternatively used in methanolysis. Conditions of acid hydrolysis were $4 \mathrm{M} \mathrm{HCl}$ $(1 \mathrm{ml}), 4 \mathrm{~h}$ at $100^{\circ} \mathrm{C}$, followed by extraction with $\mathrm{n}$-hexane and methylation by ethereal diazomethane. Saponification was performed essentially as described by Lambert \& Moss (1983). Briefly, the cells were first suspended in $1 \mathrm{ml} 15 \%$ (w/v) $\mathrm{NaOH}$ in $50 \%(\mathrm{v} / \mathrm{v})$ aqueous methanol, and heated at $100^{\circ} \mathrm{C}$ for $30 \mathrm{~min}$. After cooling, $1.2 \mathrm{ml} \mathrm{HCl} /$ methanol reagent $(25 \mathrm{ml}$ of $37 \% \mathrm{HCl}$ mixed with $75 \mathrm{ml}$ methanol) was added, and the vial was further heated at $80^{\circ} \mathrm{C}$ for $10 \mathrm{~min}$. The mixture was extracted with diethyl ether/hexane $(1: 2, \mathrm{v} / \mathrm{v})$ and treated with ethereal diazomethane. The internal standard in the Megasphaera samples was $\mathrm{n}$-heptadecanoic acid (100 $\mu \mathrm{g}$, Sigma). Trimethylsilylation of fatty acid methyl esters (FAMEs) was done with N,O-bis(trimethylsilyl)trifluoroacetamide (BSTFA, Fluka) by treating dried aliquots of the methanolysates with $25 \mu$ l BSTFA for $2 \mathrm{~h}$ at $65^{\circ} \mathrm{C}$.

Gas chromatography and mass spectrometry. Gas chromatography (GLC) was carried out with a Hewlett-Packard 5890 gas chromatograph equipped with a flame ionization detector (FID). Quantification of FAMEs and 1,1dimethylacetals (DMAs) was performed with a $25 \mathrm{~m} \times 0.32 \mathrm{~mm}$ phenyl methyl silicone fused silica capillary column (HP-5, Hewlett-Packard). The carrier gas was helium. The temperature programme was $170^{\circ} \mathrm{C}$ isothermally for $3 \mathrm{~min}$, then by $5^{\circ} \mathrm{C} \mathrm{min}^{-1}$ to $260^{\circ} \mathrm{C}$. Temperatures of the injector and the detector were $260^{\circ} \mathrm{C}$ and $280^{\circ} \mathrm{C}$, respectively. For identification of isomeric unsaturated FAMEs, samples were also analysed using a polar column NB-9C $(25 \mathrm{~m} \times 0.32 \mathrm{~mm}$, HNU-Nordion, Helsinki) which was operated from $140^{\circ} \mathrm{C}$ (isothermally for $3 \mathrm{~min}$ ) to $260^{\circ} \mathrm{C}$, increasing $5^{\circ} \mathrm{C} \mathrm{min}{ }^{-1}$. Standard mixtures $\left(\mathrm{C}_{12}-\mathrm{C}_{18}\right)$ containing known amounts of saturated, unsaturated, and hydroxy FAMEs were analysed before and after each set of analyses, to evaluate chromatographic performance and to obtain response factors for quantification of different fatty acid classes. Typically, the FID responses for saturated and unsaturated FAMEs were directly proportional to the amount of analyte (response factor $=1 \cdot 00$ ), whereas for 3-hydroxy acids the response was lower (response factor $=1 \cdot 11$ ). For DMAs a response factor of 1.00 was used.

All mixtures were analysed by combined gas chromatography and mass spectrometry (GLC-MS), using a 5890 gas chromatograph equipped with a $25 \mathrm{~m} \times 0.2 \mathrm{~mm}$ HP-5 column connected to a HP5971A mass-selective detector (HewlettPackard). The temperature programme was $170^{\circ} \mathrm{C}$ isothermally for $3 \mathrm{~min}$, then increasing by $5^{\circ} \mathrm{C} \mathrm{min}^{-1}$ to $280^{\circ} \mathrm{C}$. Temperatures of the injector and the interface were $260^{\circ} \mathrm{C}$ and $280^{\circ} \mathrm{C}$, respectively. Electron impact mass spectra were recorded at $70 \mathrm{eV}$. Saturated, unsaturated and cyclopropane FAMEs normally yielded ions corresponding to $M^{+}$, and diagnostic fragment ions were screened for the identification of different fatty acid classes as described elsewhere (Asselineau \& Asselineau, 1984; Wollenweber \& Rietschel, 1990). DMAs yielded, besides ions $M^{+}$and $M-31^{+}$, the ion at $m / z 75$ as the base peak. Chemical ionization mass spectra were acquired with ammonia as the reactant gas.

Beer samples. A bottle of commercial Finnish beer was inoculated with a drop of an actively growing culture of $P$. frisingensis ATCC 33332 and incubated at $30^{\circ} \mathrm{C}$ until turbidity developed. Aliquots $(1 \mathrm{ml})$ from the beer were freeze-dried, as were similar samples from uncontaminated beer. The dried materials were subjected to saponification as described above.

\section{RESULTS}

\section{Identification of fatty acids and alk-1-enyl chains: technical considerations}

Fatty acids (including alk-1-enyl chains) were analysed from M. cerevisiae strains DSM 20462 and VTT E-84195 and, for comparison, from $M$. elsdenii, which is the only species previously assigned to this genus. In addition, type strains of $P$. cerevisiiphilus and $P$. frisingensis were analysed. For each of these strains, cellular fatty acid analysis by methanolysis and saponification, respectively, yielded markedly different chromatograms, as exemplified in Figs 1 and 2 for $P$. cerevisiiphilus. Analysis of the methanolysate revealed a pattern of saturated, unsatu-

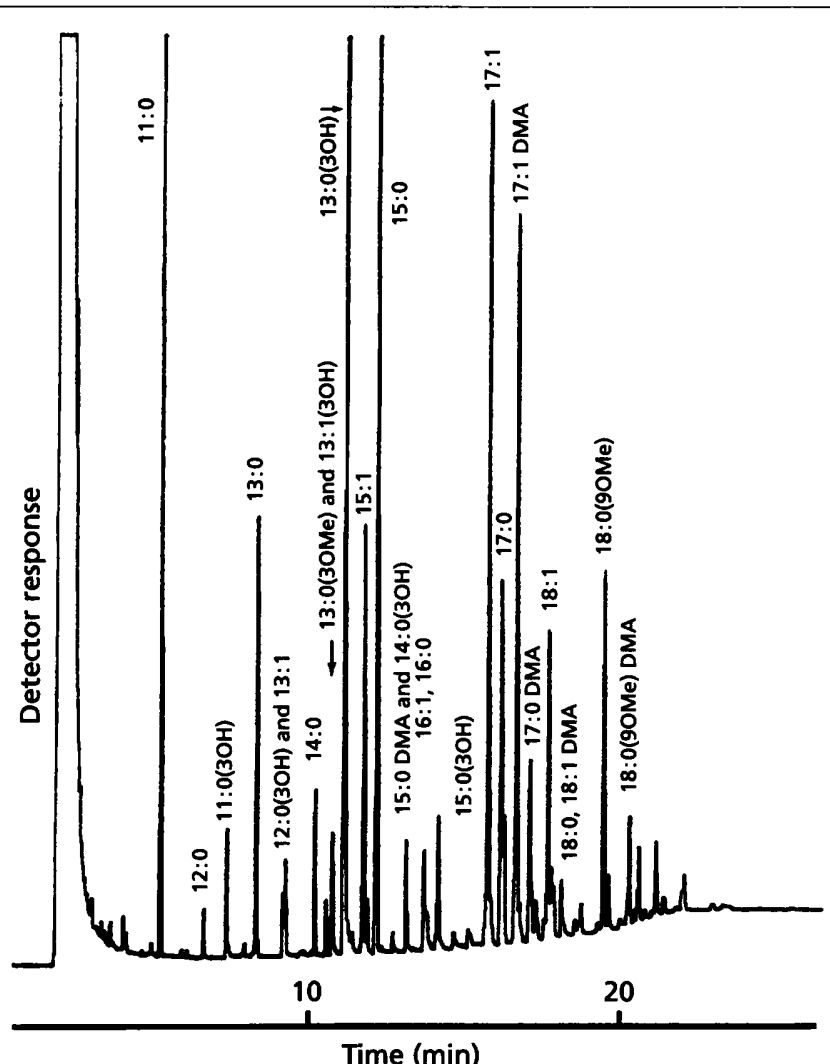

Fig. 1. Gas chromatogram of cellular fatty acids and alk-1-enyl chains of $P$. cerevisiiphilus prepared by methanolysis. The analysis was carried out with flame ionization detection on a HP-5 column with a temperature programme from $170^{\circ} \mathrm{C}$ (isothermally for $3 \mathrm{~min}$ ) to $260^{\circ} \mathrm{C}$, increasing at $5^{\circ} \mathrm{C} \mathrm{min}-1$. Peaks arise from FAMEs and DMAs. The notation includes the number of carbon atoms, double bonds, and hydroxylation or O-methylation, respectively. 


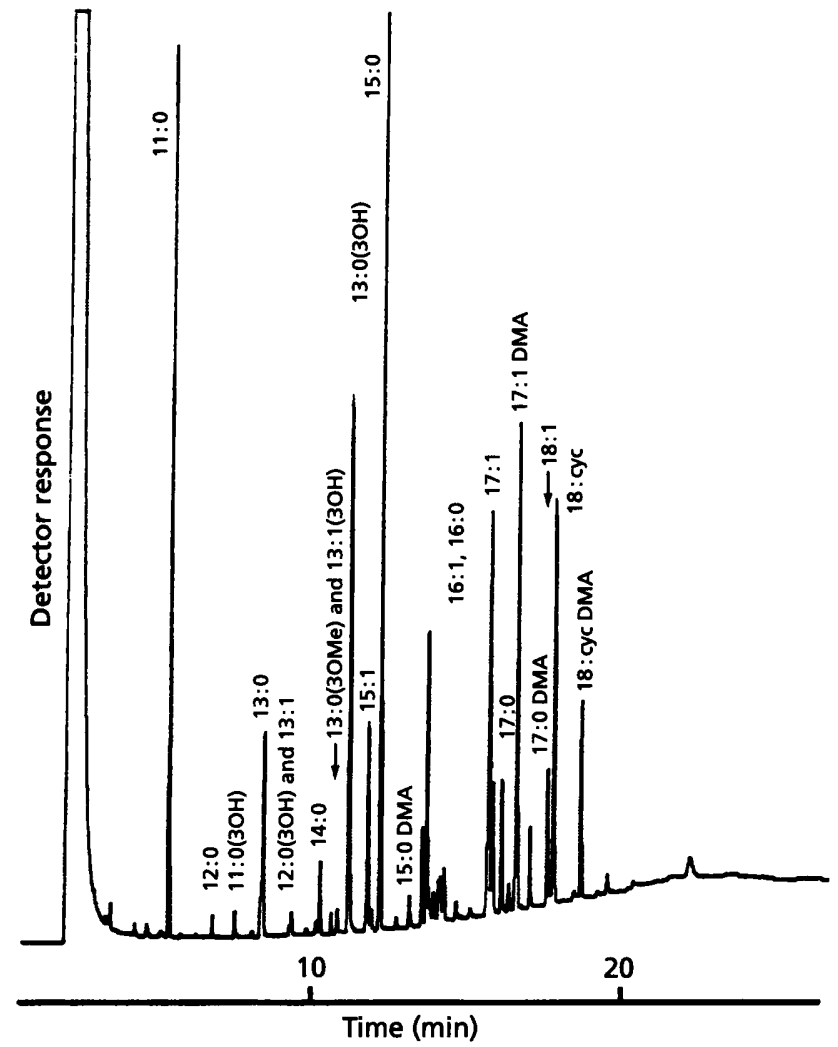

Fig. 2. Gas chromatogram of cellular fatty acids of $P$. cerevisiiphilus prepared by saponification. Chromatographic details were as in Fig. 1.

rated, and 3-hydroxylated FAMEs, DMAs and several methoxy FAMEs (Fig. 1). Since 3-hydroxy fatty acids are known to produce significant amounts of the corresponding 3 -methoxy and $\alpha, \beta$-unsaturated fatty acids as artefacts in various analytical procedures (Wollenweber \& Rietschel, 1990), the presence of small amounts of $13: 1$ and 13:0(3OMe) derived from the major 3-hydroxy acid, $13: 0(3 \mathrm{OH})$ was expected in the chromatograms of $P$. cerevisiiphilus, and they were added to $13: 0(3 \mathrm{OH})$ in the subsequent quantification. However, the methanolysate also contained several other peaks which were identified by GLC-MS as methoxy FAMEs and DMAs; notably, 18:0(9OMe) was detected as the major component among these substances. Analysis of $P$. cerevisiiphilus cells by methanolysis in $\mathrm{CD}_{3} \mathrm{OD}$ yielded 18:0(9OMe), in which not only the carboxymethyl group but also the 9-methoxy group contained three deuterium atoms instead of hydrogen atoms, as indicated by the base peak (carboxyterminal fragment cleaved between C9 and C10) at $\mathrm{m} / \mathrm{z}$ 207 . In the nondeuterium methanolysate this fragment was observed at $m / z 201$. It was thus concluded that the 9-methoxy group was artificially created during methanolysis, most likely from a cyclopropane acid as described by Vulliet et al. (1974). This was verified by analysis of the saponified sample (Fig. 2), in which no 9methoxy acids were found; instead, two major peaks were present which were absent from the methanolysate. These were analysed by GLC-MS, and were identified as methylene 9,10-heptadecanoic acid FAME (18:cyc) and the corresponding DMA. By similar techniques cyclopropane fatty acids and alk-1-enyl chains were identified also in P. frisingensis and in each Megasphaera strain.

In addition to the formation of artefacts, chromatograms obtained from methanolysed versus saponified samples differed in that the proportions of 3-hydroxy FAMEs were low in the saponified samples. Typically, the latter yielded only $65 \%$ of the amount of the major 3-hydroxy FAME found in methanolysis. In Gram-negative bacteria, 3-hydroxy fatty acids are components of the lipid A part of the LPS of the outer membrane, and some of the 3hydroxy fatty acids in each lipid A molecule are always amide-linked (Zähringer et al., 1994). The amide-linked fatty acids require strong acid-catalysed conditions for liberation, and are not properly released by saponification. Therefore, it is generally agreed that to obtain reliable fatty acid patterns from bacteria with good coverage of the relatively alkali-stable amide-linked (hydroxy) fatty acids and acid-labile cyclopropane fatty acids, two methods in combination are needed (Lambert \& Moss, 1983; Wollenweber \& Rietschel, 1990; Mayberry \& Lane, 1993). Accordingly, we combined the proportions of cellular fatty acids and alk-1-enyl chains as shown in Table 1, counting the proportions of fatty acids and alk1-enyl groups other than those with cyclopropane chains from the methanolysis data. The proportion of cyclopropane fatty acids and cyclopropane alk-1-enyl chains were counted from data obtained by saponification.

\section{The genus Megasphaera}

It is evident from Table 1 that the fatty acid and alk-1-enyl chain composition of $M$. cerevisiae and $M$. elsdenii differed only slightly. The two strains of $M$. cerevisiae yielded practically identical patterns (data not shown for strain VTT E-84195). The pattern of saturated fatty acids differed in that 10:0 was exclusively present in $M$. cerevisiae, and the proportion of 16:0 was larger in $M$. elsdenii. The unsaturated fatty acids were dominated by 18:1 $\omega 9$ cis (oleic acid) in both species, and they also contained 17 : cyc and 19: cyc fatty acids. Three different 3 hydroxy fatty acids were detected in $M$. cerevisiae, the dominant one being 14:0(3OH). Several alk-1-enyl compounds with saturated, unsaturated, and cyclopropyl chains were detected; they generally displayed chain lengths and types which were also present in fatty acids. Alk-1-enyl chains accounted for $14 \%$ of the analysed material in both Megasphaera species.

\section{The genus Pectinatus}

$P$. cerevisiiphilus and $P$. frisingensis displayed a striking predominance of odd-numbered fatty acids and alk-1-enyl chains. Among the saturated FAMEs, $11: 0$ and 15:0 were the most abundant ones, and the rare 17:1 and its alk-1enyl analogue dominated among the unsaturated chains. Altogether six different 3-hydroxy fatty acids were detected in $P$. cerevisiiphilus and $P$. frisingensis, their proportions being similar in the two species. Their identity was additionally confirmed by GLC-MS analysis 
Table 1. Fatty acid composition of $M$. cerevisiae, $M$. elsdenii, $P$. cerevisiiphilus and $P$. frisingensis

Compositions are expressed as percentages of total fatty residues, combined from analyses by methanolysis and saponification. Results are means of three determinations that did not vary by more than $5 \%$ from the mean.

\begin{tabular}{|c|c|c|c|c|}
\hline Component & $\begin{array}{l}\text { M. cerevisiae } \\
\text { DSM } 20462\end{array}$ & $\begin{array}{c}\text { M. elsdenii } \\
\text { ATCC } 25940\end{array}$ & $\begin{array}{l}\text { P. cerevisiiphilus } \\
\text { ATCC } 29359\end{array}$ & $\begin{array}{l}\text { P. frisingensis } \\
\text { ATCC } 33332\end{array}$ \\
\hline \multicolumn{5}{|c|}{ Saturated fatty acids } \\
\hline $10: 0$ & $2 \cdot 9$ & ND & ND & ND \\
\hline $11: 0$ & ND & ND & $10 \cdot 1$ & $9 \cdot 7$ \\
\hline $12: 0$ & $4 \cdot 7$ & $9 \cdot 8$ & 0.3 & 0.5 \\
\hline 13:0 & ND & ND & $3 \cdot 0$ & $4 \cdot 1$ \\
\hline $14: 0$ & $2 \cdot 0$ & $2 \cdot 1$ & $1 \cdot 1$ & 0.6 \\
\hline $15: 0$ & $0 \cdot 3$ & $0 \cdot 1$ & $16 \cdot 8$ & $11 \cdot 0$ \\
\hline $16: 0$ & $4 \cdot 9$ & $12 \cdot 4$ & $1 \cdot 1$ & 0.8 \\
\hline $17: 0$ & ND & ND & $2 \cdot 9$ & $2 \cdot 4$ \\
\hline $18: 0$ & 0.7 & $4 \cdot 3$ & $0 \cdot 6$ & $1 \cdot 0$ \\
\hline \multicolumn{5}{|c|}{ Unsaturated fatty acids } \\
\hline $15: 1^{*}$ & ND & ND & 3.5 & $2 \cdot 6$ \\
\hline $16: 1 \omega 7 c i s$ & $4 \cdot 5$ & 6.9 & ND & ND \\
\hline $16: 1 \omega 7$ trans & ND & ND & 0.3 & 0.5 \\
\hline $16: 1^{*}$ & $2 \cdot 7$ & $3 \cdot 0$ & ND & ND \\
\hline $17: 1^{*}$ & ND & ND & 6.8 & $4 \cdot 0$ \\
\hline $18: 1 \omega 9$ cis & $9 \cdot 7$ & 11.8 & $2 \cdot 6$ & 0.8 \\
\hline $18: 1 \omega 9$ trans & $1 \cdot 8$ & $1 \cdot 6$ & 0.7 & 0.4 \\
\hline \multicolumn{5}{|c|}{ Cyclopropane fatty acids } \\
\hline $17:$ сус & $5 \cdot 6$ & $5 \cdot 4$ & ND & ND \\
\hline $18:$ cyc & ND & ND & $8 \cdot 1$ & $10 \cdot 5$ \\
\hline $19:$ cyc & 13.8 & 7.6 & ND & ND \\
\hline \multicolumn{5}{|c|}{ Hydroxy fatty acid } \\
\hline $11: 0(3 \mathrm{OH})$ & ND & ND & 0.8 & 0.8 \\
\hline $12: 0(3 \mathrm{OH})$ & $4 \cdot 6$ & $3 \cdot 9$ & $0 \cdot 4$ & 0.5 \\
\hline $13: 0(3 \mathrm{OH})$ & $2 \cdot 5$ & TR & $24 \cdot 9$ & $26 \cdot 1$ \\
\hline $13: 1(3 \mathrm{OH})$ & ND & ND & $1 \cdot 1$ & 0.5 \\
\hline $14: 0(3 \mathrm{OH})$ & $22 \cdot 1$ & $17 \cdot 4$ & $0 \cdot 3$ & $0 \cdot 4$ \\
\hline $15: 0(3 \mathrm{OH})$ & ND & ND & $0 \cdot 1$ & $0 \cdot 3$ \\
\hline \multicolumn{5}{|c|}{ Alk-1-enyl chains } \\
\hline $15: 0$ & ND & ND & $0 \cdot 6$ & $1 \cdot 2$ \\
\hline $16: 0$ & $2 \cdot 0$ & 3.5 & ND & ND \\
\hline $16: 1^{*}$ & $1 \cdot 4$ & $2 \cdot 6$ & ND & ND \\
\hline $17: 0$ & ND & ND & $2 \cdot 0$ & $4 \cdot 2$ \\
\hline $17: 1^{*}$ & ND & ND & $6 \cdot 2$ & $4 \cdot 7$ \\
\hline $18: 0$ & 0.7 & 0.7 & ND & ND \\
\hline $18: 1^{*}$ & $1 \cdot 1$ & $3 \cdot 0$ & ND & $0 \cdot 8$ \\
\hline $17:$ cyc & $4 \cdot 3$ & $2 \cdot 4$ & ND & ND \\
\hline $18:$ cyc & ND & ND & $5 \cdot 7$ & $11 \cdot 6$ \\
\hline 19:cyc & $4 \cdot 6$ & $1 \cdot 5$ & ND & ND \\
\hline
\end{tabular}

ND, None detected; TR, $<0 \cdot 1 \%$, detectable by selective ion monitoring.

* Isomeric form not determined.

of 3-O-trimethylsilyl (TMS) ether methyl ester derivatives, which yielded prominent (usually base peak) fragments at $m / z M-15$. Among the hydroxy fatty acids the most abundant was 13:0(3OH), which was also the major cellular fatty acid. A minor FAME eluted slightly before 13:0(3OH) from the HP-5 column, in both methanolysed and saponified samples (Figs 1 and 2). This compound yielded a mass spectrum reminiscent of a 3-hydroxy fatty acid, as indicated by the prominent fragment ion at $m / z 103$. Fragment ions at $m / z 224$ and 150 , assigned to ions $M-18^{+}$and $M-18-74^{+}$, indicated a molecular mass of 242. GLC-MS of the TMS ether methyl esterderivatives confirmed that this fatty acid had a molecular mass that was two mass units lower than that of the $13: 0(3 \mathrm{OH})$, as indicated by the $M-15$ fragments at $m / z$ 299 and 301, respectively. This fatty acid was thus 


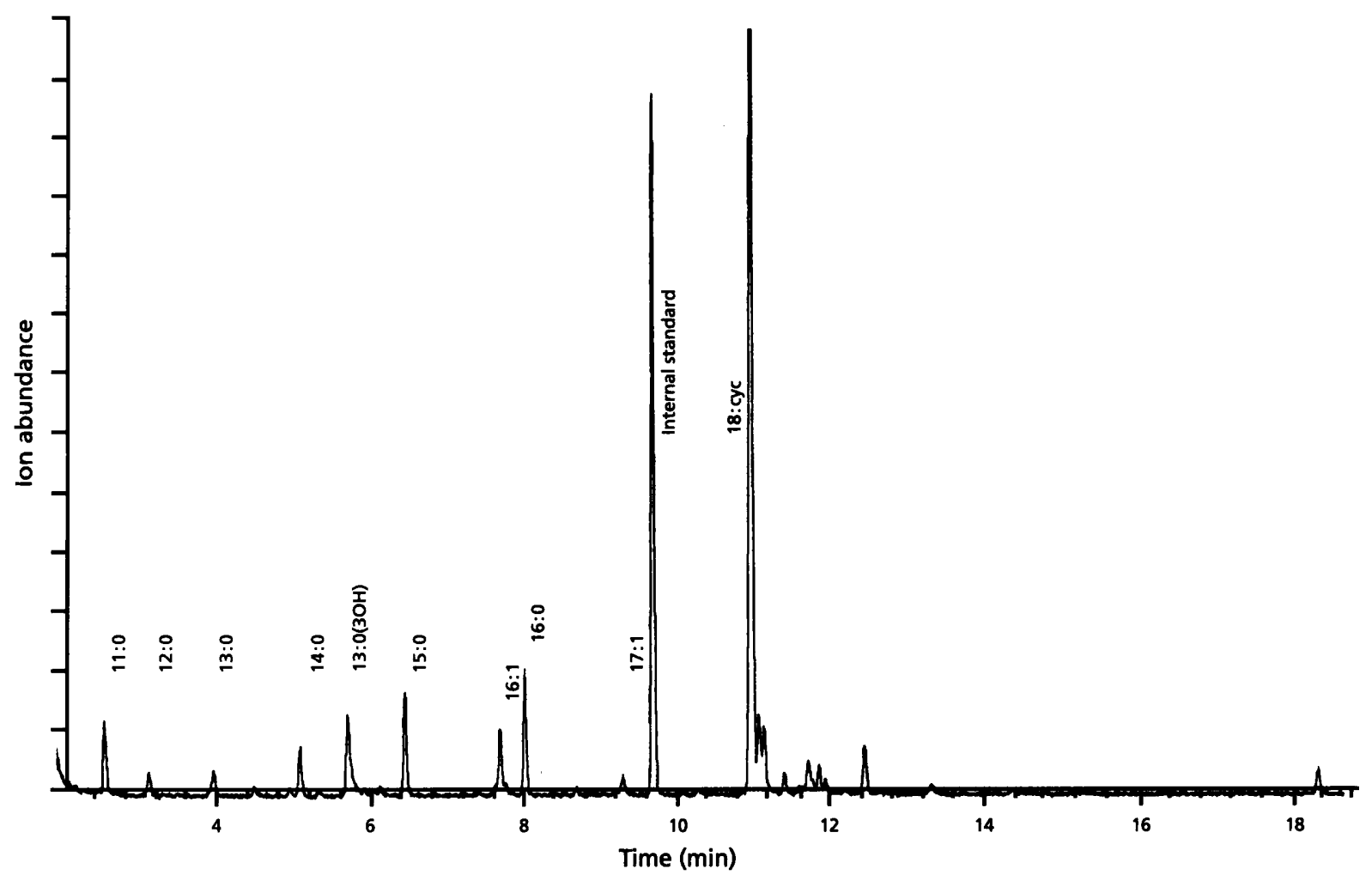

Fig. 3. Gas chromatogram (total ion chromatogram from GLC-MS) of a saponified $1 \mathrm{ml}$ sample of beer in which $P$. frisingensis was growing. The amount of internal standard (17:0) was $100 \mu \mathrm{g}$, and $1 \mu \mathrm{l}$ out of $100 \mu \mathrm{l}$ was injected.

identified as 13:1(3OH). Alk-1-enyl chains accounted for $15 \%$ of analysed material in P. cerevisiiphilus and $23 \%$ in $P$. frisingensis. The latter was particularly rich in the alk1-enyl group with the 18 : cyc chain.

\section{Analysis of contaminated beer}

To assess whether fatty acid analysis could be applied to detection of bacterial contamination in beer, we analysed by saponification a $1 \mathrm{ml}$ aliquot of beer in which $P$. frisingensis was growing. In parallel, a similar sample of uncontaminated beer was analysed. The analysis (Fig. 3) of the contaminated beer sample revealed FAMEs including 18: cyc, 13:0(3OH), and other odd-numbered fatty acids, which are characteristic for Pectinatus. The uncontaminated beer analysed by this technique yielded only a minor peak of 16:0, accounting for less than $1 \mu \mathrm{g}$ fatty acid per $\mathrm{ml}$ beer.

\section{DISCUSSION}

The cellular fatty acid analysis revealed, both in Megasphaera and in Pectinatus, considerable proportions of alk-1-enyl chains in addition to acyl chains, indicating the presence of plasmalogens in these bacteria. Among the prokaryotes, plasmalogens are typically found in strictly anaerobic bacteria, including both Gram-positive and Gram-negative species (for a review see Goldfine, 1982); they have been well characterized, for instance, in $M$. elsdenii (Van Golde et al., 1973; Johnston \& Goldfine,
1982). M. cerevisiae and Pectinatus species thus represent no exception.

The fatty acyl and alk-1-enyl composition of two isolates of $M$. cerevisiae were nearly identical. Furthermore, the composition of $M$. cerevisiae closely resembled that of $M$. elsdenii, differing only in the quantitative proportions of some fatty acids. Our results for M. elsdenii agree well with the fatty acyl and alk-1-enyl composition reported for phospholipids of $M$. elsdenii ATCC 17752 (Johnston \& Goldfine, 1982). There is no information concerning the LPS composition in the genus Megasphaera, but it is likely that the 3-hydroxy fatty acids detected are LPS components.

The striking predominance of odd-numbered fatty acyl and alk-1-enyl chains of both $P$. cerevisiiphilus and $P$. frisingensis is a remarkable property seldom encountered among bacteria. In this respect Pectinatus species closely resemble Veillonella alcalescens and $V$. parvula, parasitic anaerobic cocci, in which the acyl and alk-1-enyl chains of phospholipids (Hewett et al., 1971; Johnston \& Goldfine, 1982), and also the LPS (Hewett et al., 1971), exhibit the same major chain lengths as Pectinatus. The major 3hydroxy fatty acid of Pectinatus, 13:0(3OH), was previously shown to be the main fatty acid substituting the lipid A backbone in both Pectinatus species (Helander $e t$ al., 1994). This fatty acid is rarely found in LPS, but has been reported in Legionella species (Sonesson et al., 1989, 1994), Pseudomonas diminuta (Wilkinson et al., 1973; Kasai 
et al., 1987) and Selenomonas ruminantium (Kamio et al., 1971). Among the minor fatty acids of $P$. cerevisiiphilus and $P$. frisingensis, the unsaturated 3-hydroxy acid 13:1(3OH) is exceptional as, to our knowledge, this fatty acid has not been previously reported in bacteria or in LPS (Wilkinson, 1988). Other unsaturated 3-hydroxy fatty acids have been sporadically found in bacteria (Wilkinson, 1988), notably in some species of Rbizobium [18:1(3-OH)] (Russa et al., 1985; Urbanik-Sypniewska et al., 1989). In the recent description of Pectinatus lipid A (Helander et al., 1994), this fatty acid was not detected. However, microheterogeneity is a common feature in the fatty acids of lipid A (Zähringer et al., 1994), and 13:1(3OH) may well be a component of this lipid, since minor fatty acids contribute little to the main structure which usually is chemically analysed for structure.

Pectinatus was included in a recent report comparing the cellular fatty acid patterns of Gram-negative anaerobes (Moore et al., 1994). Our results disagree in several major fatty acids: Moore and co-workers reported no 13:0(3OH), which in our present study was the most abundant fatty acid ( $25 \%$ of total), and which we have on several occasions reported as the main fatty acid of Pectinatus LPS (Helander et al., 1983, 1992, 1994), nor did they detect any cyclopropane fatty acids. Instead, they report $18 \%$ of 14:0 DMA, which was not present in our Pectinatus strains, and a large proportion of 18:1 DMA which was a minor component ( $<1 \%$ of total) in $P$. frisingensis and not detectable in $P$. cerevisiiphilus. We believe that Moore and co-workers have erroneously identified these FAMEs and DMAs by relying on GLC retention times only.

Finally, the fatty acid analysis was shown to be applicable for the detection of bacterial contamination in beer. As was also found in our experiment, fatty acids with carbon chains between $\mathrm{C}_{12}$ and $\mathrm{C}_{18}$ have been reported to exist in beer in submicrogram amounts per $\mathrm{ml}$ (Wackerbauer \& Bender, 1983). The low amount of saponifiable fatty acids in uncontaminated beer will make it possible to detect small amounts of bacterial fatty acids in beer samples, possibly also allowing the determination of the type of contaminant on the basis of the types of fatty acids detected.

\section{ACKNOWLEDGEMENTS}

We thank Juha Ahvenainen and Pertti Martikainen for fruitful discussions.

\section{REFERENCES}

Asselineau, C. \& Asselineau, J. (1984). Fatty acids and complex lipids. In Gas Cbromatography Mass Spectrometry. Applications in Microbiology, pp. 57-103. Edited by G. Odham, L. Larsson \& P.-A. Mårdh. New York: Plenum Press.

Engelmann, U. \& Weiss, N. (1985). Megasphaera cerevisiae sp. nov.: a new Gram-negative obligately anaerobic coccus isolated from spoiled beer. Syst Appl Microbiol 6, 287-290.

Goldfine, H. (1982). Lipids of prokaryotes - structure and distribution. Curr Top Membr Transp 17, 1-43.
Haikara, A. (1991). The genera Pectinatus and Megasphaera. In The Prokaryotes, 2nd edn., pp. 1993-2004. Edited by A. Balows, H. G. Trüper, M. Dworkin, W. Harder \& K.-H. Schleifer. New York: Springer-Verlag.

Helander, I., Hakalehto, E., Ahvenainen, J. \& Haikara, A. (1983). Characterization of lipopolysaccharides of Pectinatus cerevisiophilus. FEMS Microbiol Lett 18, 223-226.

Helander, I. M., Hurme, R., Haikara, A. \& Moran, A. P. (1992). Separation and characterization of two chemically distinct lipopolysaccharides in two Pectinatus species. J Bacteriol 174, 3348-3354.

Helander, I. M., Kilpeläinen, I., Vaara, M., Moran, A. P., Lindner, B. \& Seydel, U. (1994). Chemical structure of the lipid A component of lipopolysaccharides of the genus Pectinatus. Eur J Biochem 224, 63-70.

Johnston, N. C. \& Goldfine, H. (1982). Effects of growth temperature on fatty acid and alk-1-enyl group compositions of Veillonella parvula and Megasphaera elsdenii phospholipids. J Bacteriol 149, 567-575.

Kamio, Y., Kim, K. C. \& Takahashi, H. (1971). Chemical structure of lipid A of Selenomonas ruminantium. J Biochem 70, 187-191.

Kasai, N., Arata, S., Mashimo, J., Akiyama, Y., Tanaka, C., Egawa, K. \& Tanaka, S. (1987). Pseudomonas diminuta LPS with a new endotoxic lipid A structure. Biochem Biophys Res Commun 142, 972-978.

Lambert, M. A. \& Moss, C. W. (1983). Comparison of the effects of acid and base hydrolyses on hydroxy and cyclopropane fatty acids in bacteria. J Clin Microbiol 18, 1370-1377.

Lee, S. Y., Mabee, M. S. \& Jangaard, N. O. (1978). Pectinatus, a new genus of the family Bacteroidaceae. Int J Syst Bacteriol 28, 582-594.

Mayberry, W. R. \& Lane, J. R. (1993). Sequential alkaline saponification/acid hydrolysis/esterification: a one-tube method with enhanced recovery of both cyclopropane and hydroxylated fatty acids. $J$ Microbiol Methods 18, 21-32.

Moore, L. V. H., Bourne, D. M. \& Moore, W. E. C. (1994). Comparative distribution and taxonomic value of cellular fatty acids in thirty-three genera of anaerobic gram-negative bacilli. Int J Syst Bacteriol 44, 338-347.

Russa, R., Luderitz, O. \& Rietschel, E. Th. (1985). Structural analyses of lipid A from lipopolysaccharides of nodulating and nonnodulating Rbizobium trifolii. Arch Microbiol 141, 284-289.

Schleifer, K. H., Leuteritz, M., Weiss, N., Ludwig, W., Kirchhof, G. \& Seidel-Rufer, H. (1990). Taxonomic study of anaerobic, Gramnegative, rod-shaped bacteria from breweries: amended description of Pectinatus cerevisiiphilus and description of Pectinatus frisingensis sp. nov., Selenomonas lacticifex sp. nov., Zymophilus raffinosivorans gen. nov., sp. nov., and Zymophilus paucivorans gen. nov., sp. nov. Int $J$ Syst Bacteriol 40, 19-27.

Sonesson, A., Jantzen, E., Bryn, K., Larsson, L. \& Eng, J. (1989). Chemical composition of a lipopolysaccharide from Legionella pneumophila. Arch Microbiol 153, 72-78.

Urbanik-Sypniewska, T., Seydel, U., Greck, M., Weckesser, J. \& Mayer, H. (1989). Chemical studies on the lipopolysaccharide of Rbizobium meliloti 10406 and its lipid A region. Arch Microbiol 152, 527-532.

Sonesson, A., Jantzen, E., Tangen, T. \& Zăhringer, U. (1994). Lipopolysaccharides of Legionella erythra and Legionella oakridgensis. Can J Microbiol 40, 666-671.

Van Golde, L. M. G., Prins, R. A., Franklin-Klein, W. \& AkkermansKruyswijk, J. (1973). Phosphatidylserine and its plasmalogen analogue as major lipid constituents in Megasphaera elsdenii. Biochim Biopbys Acta 326, 314-323.

Vulliet, P., Markey, S. P. \& Tornabene, T. G. (1974). Identification 
of methoxyester artifacts produced by methanolic- $\mathrm{HCl}$ solvolysis of the cyclopropane fatty acids of the genus Yersinia. Biochim Biophys Acta 348, 299-301.

Wackerbauer, K. \& Bender, G. (1983). Die Bedeutung der freien Fettsäuren und Fettsäure-Äthylester während der Gärung und Lagerung. Monatssch Brawwiss 36, 152-158.

Wilkinson, S. G. (1988). Gram-negative bacteria. In Microbial Lipids, vol. 1, pp. 299-488. Edited by C. Ratledge \& S. G. Wilkinson. London: Academic Press.
Wollenweber, H.-W. \& Rietschel, E. T. (1990). Analysis of lipopolysaccharide (lipid A) fatty acids. J Microbiol Methods 11, 195-211.

Zăhringer, U., Lindner, B. \& Rietschel, E. T. (1994). Molecular structure of lipid $A$, the endotoxic center of bacterial lipopolysaccharides. Adv Carbobydr Chem Biochem 50, 211-276.

Received 5 December 1994; revised 13 January 1995; accepted 20 January 1995. 